\title{
AN ANAESTHETIC APPLICATION OF SERUM DIGOXIN RADIOIMMUNOASSAY*
}

\author{
RoDerick K. Calverley, M.D., F.R.C.P.(C) $†$
}

Despite an unRivalled role in the therapy of congestive heart failure, digitalis is a drug with a narrow margin of safety. The low therapeutic index of digitalis preparations is reflected in a high incidence of toxic manifestations, most notably cardiac dysrhythmias and disturbances of conduction. A current prospective study demonstrates a 23 per cent incidence of digitalis toxicity among 134 digitalized patients assessed at the time of admission to hospital."

\section{Digoxin Pharmacokinetics}

The hazard of digitalis intoxication has stimulated an intensive study of the pharmacokinetics of radioactively-labelled digitalis preparations." Much of this interest has been focused on digoxin, the most popular form of digitalis in many hospitals.

The absorption of digoxin is nearly complete. Eighty to 85 per cent of an oral dose of digoxin is absorbed by patients with normal intestinal function. ${ }^{3} \mathrm{De}$ creased absorption has been observed in patients with malabsorption syndromes. ${ }^{4}$

The distribution of digoxin has been investigated. Tissue concentrations are highest in the myocardium and kidney. ${ }^{5}$ Skeletal muscle concentrations are much lower, but the relatively large mass of skeletal muscle represents a site of storage and subsequent release of digoxin which may maintain stable serum levels. ${ }^{6}$ Less than 1 per cent of total body digoxin is present in the serum or plasma of digitalized patients and of this small fraction only 23 per cent is loosely bound to albumin. ${ }^{7,8}$

In contrast to digitoxin, only a small fraction of digoxin undergoes metabolic transformation."

Digoxin is mainly excreted in the urine. In patients with normal renal function the rate of excretion reflects a first-order logarithmic curve with a half-time of 34 hours. ${ }^{10}$ About 35 per cent of total digoxin is excreted by these patients in a 24-hour period." With diminishing renal function the half-time of excretion becomes progressively longer and may be as long as 4.4 days in the anephric patient. ${ }^{12}$ Patients without any renal function excrete 14 per cent of total body digoxin stores each day by various nonurinary routes, predominantly in the bile. ${ }^{13,14}$ Dialysis is not an effective treatment for digoxin intoxication since the concentration gradient between plasma and the dialysate is extremely low. ${ }^{15}$

There is a relatively constant relationship between serum and myocardial tissue

"Yresented in the Resident's Competition of the 1971 Canadian Anaesthetists' Society Meeting, June 29, 1971 .

†From The Department of Anaesthesia and the Department of Nuclear Medicine, Vancouver General Hospital, Vancouver, BC.

Canad, Anaesth. Soc. J., vol. 19, no. 1, January 1972 
concentrations of digoxin except for a transient elevation following the ingestion or injection of the drug. ${ }^{16,17}$ After oral administration plasma levels reach a peak within 30 to 60 minutes and return to a plateau within 6 to 8 hours. ${ }^{18}$ Experimental studies in animals have demonstrated that even when therapy is discon. tinued, the level of tissue stores are paralleled in diminishing serum levels. ${ }^{10,20}$

\section{Serum Digoxin Radioimmunoassay}

The relationship between senum levels and myocardial tissue stores has prompted an intense interest in the development of serum assays as an indirect determination of myocardial concentrations. In the past, several techniques employing bioassay, chromatography and other methods have been exceedingly complex. ${ }^{21,22}$

The first clinically practical test to be developed is serum digoxin radioimmunoassay. ${ }^{2 \pi, 24}$ (See appendix.) The test is specific and precise. A digoxin-specific antibody is prepared by injecting rabbits with a digoxin-albumin conjugate. The test is performed by measuring the competition for antibody binding between the digoxin present in the patient's serum and tritiated digoxin added to the test tube. The Department of Nuclear Medicine of the Vancouver General Hospital employs a commercial digoxin radioimmunoassay kit. ${ }^{\circ}$ Each determination is performed twice. While results are reported in increments of 0.1 nanogram per milliliter $(\mathrm{ng} / \mathrm{ml}$ ) of serum, two determinations on the same specimen may show variations of $0.2 \mathrm{ng} / \mathrm{ml}$ which is the expected range of variation of the test (One nanogram $=1 \times 10^{-9}$ gram).

It is not yet possible to define the optimum therapeutic value of senum digoxin for any individual patient, but values below $2.0 \mathrm{ng} / \mathrm{ml}$ are considered to be in the non-toxic range. ${ }^{25,26}$ Serum values below $0.4 \mathrm{ng} / \mathrm{ml}$ suggest underdigitalization. ${ }^{27}$ Smith and Haber ${ }^{28}$ have observed that in their series 87 per cent of patients with digoxin toxicity had serum levels of $2.0 \mathrm{ng} / \mathrm{ml}$ or greater and that 90 per cent of patients without digoxin toxicity had $2.0 \mathrm{ng} / \mathrm{ml}$ or less. The overlap between the two groups of patients is very narrow. Other clinical trials have demonstrated the clinical value of this test. ${ }^{23-31}$ Toxic levels are caused by excessive administration or inadequate renal elimination.

It must be emphasized that serum digoxin radioimmunoassay is only a guide to management and is not designed to supplant frequent, careful examination as an assessment of the patient's response to therapy.

\section{Anaesthetic Application of Serum Digoxin Radionmmunoassay}

Since the problems of digoxin intoxication and underdigitalization are accentuated during and after surgical stress, the anaesthesiologist has a particular interest in the problems of the digitalized patient. In an attempt to determine the application of this test in anaesthetic practice, four areas of importance were assessed in this study. These were:

(1) The adequacy of preoperative maintenance digoxin therapy.

- Digoxin Radiotmmunoassay Kit: Schwarz-Mann Division of Becton, Dickinson \& Co. Orangeburg, NY 10962. This company also offers a Digitoxin Radioimmunoassay Kit which was not available when the study was performed. 
(2) The potential changes in serum digoxin concentration during general anaesthesia, spinal anaesthesia and cardio-pulmonary bypass. If significant changes were present, these might reflect redistribution of the drug from tissue stores during anaesthesia. Potential drug interactions causing redistribution might contribute to the increased frequency of cardiac dysrhythmias noted during anaesthesia in digitalized patients. ${ }^{32}$

(3) The application of the test in the investigation of preoperative dysrhythmias.

(4) The role of the test in the diagnosis of preoperative and postoperative digoxin intoxication.

\section{METHOD OF STUdY}

Serial venous specimens were drawn from forty-two adult patients taking digoxin. Ten others had individual samples drawn in response to requests for diagnostic assistance. Each determination was performed in duplicate. In every case digoxin was withheld for at least twelve hours before serum samples were taken.

Serum electrolytes were drawn simultaneously with every digoxin specimen. Whenever possible arterial blood gas analysis was performed at the same time. The blood urea nitrogen and serum creatinine was determined in every case. When the patients had been catheterized, urine output was recorded and urinary electrolyte values were obtained. Electrocardiographic monitoring was performed routinely.

No modification of anaesthetic technique was requested and the attending anaesthesiologist selected the technique and drugs he wished to employ.

\section{Results and Observations}

\section{Paeoperative Samples}

A wide range of preoperative values was noted which ranged from 0.2 to 3.2 $\mathrm{ng} / \mathrm{ml}$. The lower levels reflected inadequate digitalization as a result of failure to take digoxin regularly. As anticipated, the higher values were noted more frequently in patients with diminished renal function. Digoxin intoxication was not recognized clinically. Thirty patients with normal renal function were in digoxin equilibrium as a result of regular ingestion of a maintenance dose. Equilibrium or a steady state is established when absorption equals loss. Figure 1 shows the wide range of response to uniform dosage. Mean values are indicated by a horizontal bar.

Preoperative emergency digitalization was carried out in two elderly women. One patient received $1.25 \mathrm{mg}$ of digoxin over 32 hours. She had an unrecognized impairment of renal function. Ten hours after her last dose, her serum digoxin was $3.2 \mathrm{ng} / \mathrm{ml}$. This is in the toxic range.

The second patient, whose surgery was cancelled due to congestive heart failure, received smaller dosages and her response was confirmed by radioimmunoassay. After therapy the preoperative level was $1.0 \mathrm{ng} / \mathrm{ml}$, a therapeutic rather than toxic level. 


\section{SERUM DIGOXIN LEVELS IN PATIENTS} WITH NORMAL RENAL FUNCTION

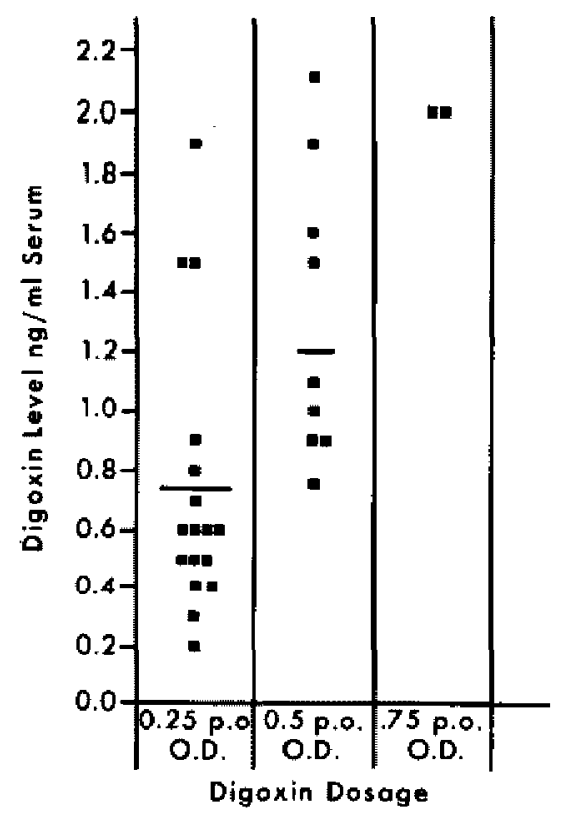

Ficure 1

\section{Preoperative Sampifis}

Several samples were drawn from each patient in the study. Since the hospital's laboratory personnel were already overtaxed in providing clinical services and accepted this experimental material as an additional responsibility, only a representative selection of patients was tested at each stage during anaesthesia.

Premedication: Seventeen patients were assessed immediately before, and one hour after receiving premedication with meperidine, diazepam and atropine either as a single drug or in varying combinations of these three drugs. No changes exceeding plus or minus $0.2 \mathrm{ng} / \mathrm{ml}$ were observed in any of these patients.

General Anaesthesia (excluding cardio-pulmonary bypass): A comparison of pre-induction and postoperative values was obtained in 14 patients whose surgery and anaesthetic time exceeded two hours (Figure 2). In only two instances did the change in serum digoxin narrowly exceed the range of variation of the test.

Since it is possible that there may be transient, yet significant, changes as a result of the administration of specific agents serial samples were taken before and after induction and during maintenance anaesthesia.

Changes during Induction: Specimens were taken immediately before and five to ten minutes after induction with combinations of succinyldicholine and other agents. Serum digoxin levels remained stable (Figure 3). 


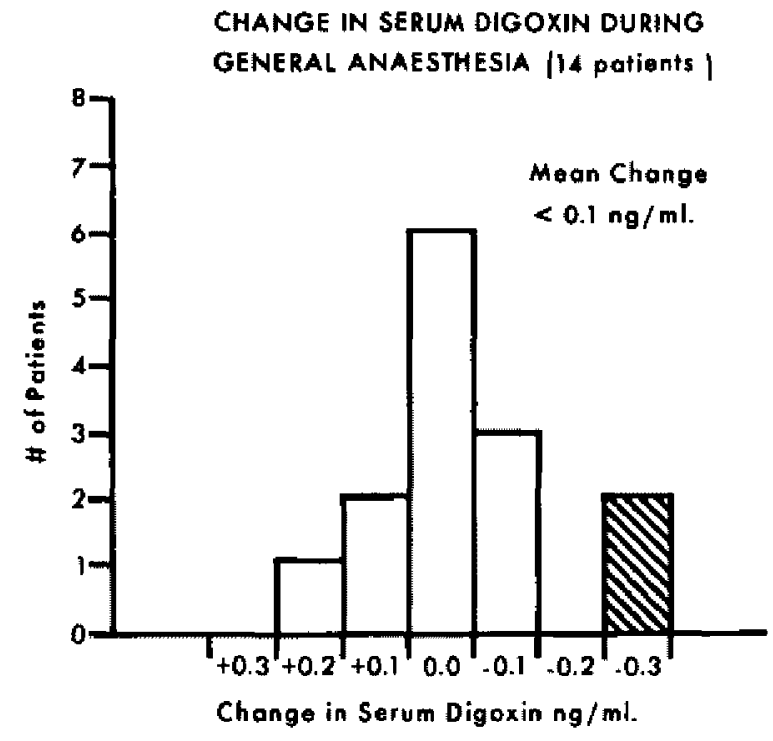

Figure 2

TABLE I

Chayges in Serum Digoxin During General Anaesthesia

\begin{tabular}{|c|c|c|c|}
\hline Anaesthetic agent & $\begin{array}{c}\text { No. of } \\
\text { patients }\end{array}$ & $\begin{array}{l}\text { Change in serum } \\
\text { digoxin }(\mathrm{ng} / \mathrm{ml})\end{array}$ & $\begin{array}{l}\text { Frequency } \\
\text { of change }\end{array}$ \\
\hline Methoxylurane & 5 & $\begin{array}{c}0 \\
-0.1 \\
-0.3\end{array}$ & $\begin{array}{l}2 \\
2 \\
1\end{array}$ \\
\hline Halothane & 6 & $\begin{array}{c}+0.1 \\
0 \\
-0.1\end{array}$ & $\begin{array}{l}3 \\
2 \\
1\end{array}$ \\
\hline Alphaprodine & 5 & $\begin{array}{r}+0.2 \\
+0.1 \\
0 \\
-0.3\end{array}$ & $\begin{array}{l}1 \\
1 \\
2 \\
1\end{array}$ \\
\hline Innovar & $\mathbf{2}$ & -0.1 & 2 \\
\hline d-tubocurare & 5 & 0 & 5 \\
\hline Gallamine & 2 & $\begin{array}{c}-0.1 \\
0\end{array}$ & $\begin{array}{l}1 \\
1\end{array}$ \\
\hline $\begin{array}{l}\text { Reversal of non-depolarizing block } \\
\text { with atropine and neostigmine }\end{array}$ & 5 & $\begin{array}{c}+0.2 \\
0 \\
-0.1 \\
-0.2\end{array}$ & $\begin{array}{l}1 \\
2 \\
1 \\
1\end{array}$ \\
\hline
\end{tabular}

\section{Changes in Serum Digoxin After Induction of General Anaesthesia}

During nitrous oxide anaesthesia specimens were taken prior to the administration of each drug, one-half hour later, and at the end of surgery. The results of these determinations are recorded in Table I. Only two changes exceeding 


\section{INDUCTION}

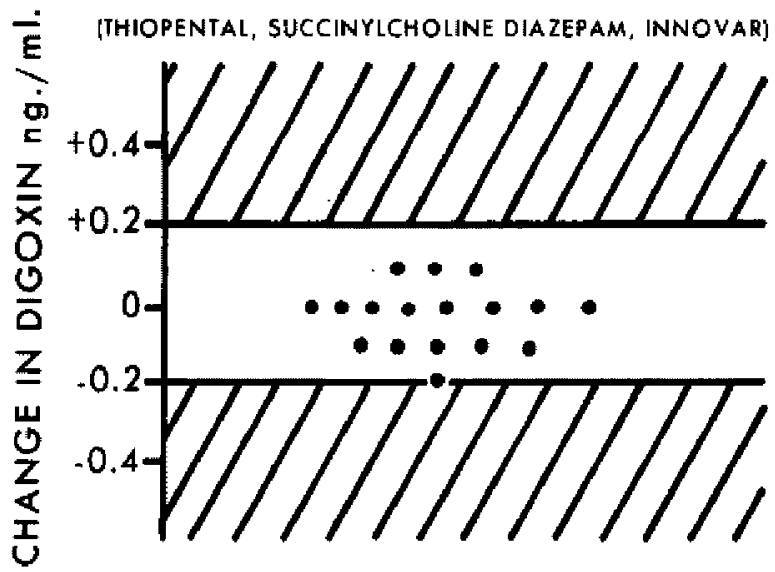

Figvie 3. Changes in serum digoxin after induction of genera] anzesthesia.

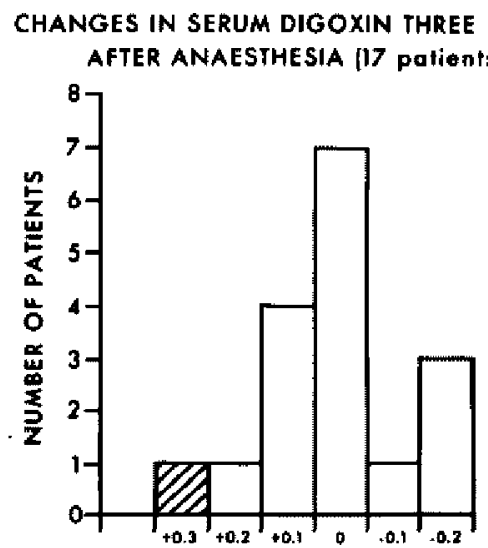

Change in Serum Digoxin ng/ml.

Figthe 4

the range of variation of the test were observed. A possible explanation in both instances may be the protracted period of anaesthesia.

\section{Postoperative Changces in Serum Digoxin}

Specimens were taken from 17 patients three hours after general anaesthesia (Figure 4). Aside from the single shaded minor rise of $0.3 \mathrm{ng} / \mathrm{ml}$ all other values lie within the range of variation of the test.

\section{Spinal ANaestresia}

Four patients provided serial samples during and after transurethral resection 


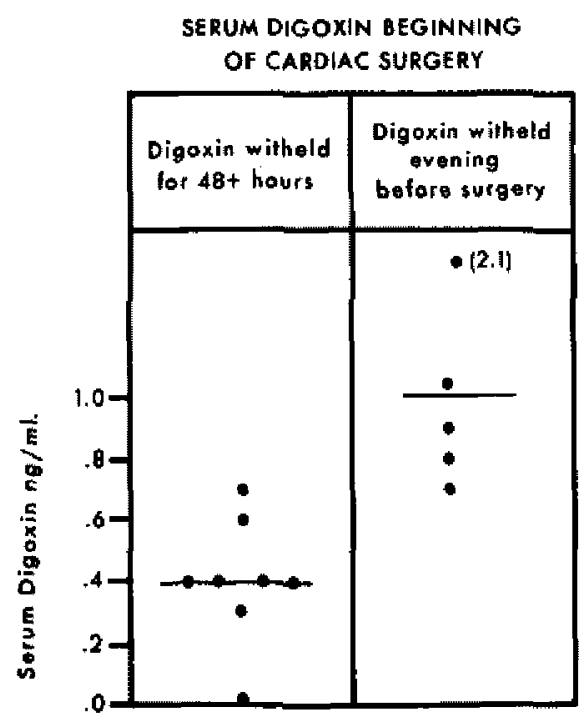

Fraune 5. Serum digoxin levels beginning of cardiac surgery.

of the prostate under tetracaine spinal anaesthesia. None of the changes in serum digoxin exceeded plus or minus $0.1 \mathrm{ng} / \mathrm{ml}$.

\section{Cardiopulmonary Bypass}

Samples for serum digoxin assay were drawn from 14 digitalized patients preoperatively, and during cardiopulmonary bypass and again in the early postoperative period. The surgical procedures included valve replacements and coronary artery bypass grafts.

Operative specimens were taken after induction of anaesthesia, before and after heparinization, before and after cardiopulmonary bypass, and at the end of surgery. Postoperative samples were taken three hours after surgery and again the following morning.

A control patient who had never taken digoxin was included. His digoxin values were zero on every sampling. Specimens drawn from the bubble or disc oxygenator priming solutions had no recordable levels of digoxin.

Preoperatively these digitalized patients could be divided into two groups as a result of the surgeon's decision to withhold digoxin for more than 48 hours before surgery or to continue digoxin until the day before surgery. (Figure 5).

The mean value of the group in which digoxin was withheld was $0.4 \mathrm{ng}$, which was $0.6 \mathrm{ng}$ lower than the mean of those patients who received digoxin until surgery. Some surgeons have stopped digoxin more than 48 hours before surgery so that they might exclude digoxin intoxication as a cause of dysrhythmias. As a consequence of this approach, several of these patients had excreted a significant proportion of their total digoxin stores prior to surgery. These patients could be 
considered to be inadequately digitalized. Three of the patients with low serum levels required aggressive redigitalization during the frst 24 hours after surgery.

The mean per-operative change among those patients in whom digoxin was discontinued was less than $-0.1 \mathrm{ng} / \mathrm{ml}$ ( range 0 to $-0.2 \mathrm{ng} / \mathrm{ml}$ ). The mean peroperative change among those patients still in equilibrium at the time of surgery was slightly larger, $-0.2 \mathrm{ng} / \mathrm{ml}$ (range +0.2 to $-0.3 \mathrm{ng} / \mathrm{ml}$ ). None of the patients in the series demonstrated significant fluctuations in serum digoxin concentrations following heparinization, cardiopulmonary bypass, defibrillation or the administration of protamine.

Beall et al. ${ }^{38}$ had previously demonstrated that less than 1.2 per cent of a single dose of tritiated digoxin was left in the pump at the end of bypass.

Changes in serum digoxin during cardiopulmonary bypass have been reported by two other groups of investigators. Morrison et al. ${ }^{34}$ recognized a mean decrease of $-0.3 \mathrm{ng}$ among 10 patients. Coltart and his associates ${ }^{35}$ describe a mean fall of $-0.4 \mathrm{ng}$ among 11 patients operated on with hypothermic technique. They suggest that the fall was due primarily to dilution of the plasma volume by the oxygenator prime and transfusion.

Analysis of the specimens collected three hours after surgery and the following morning demonstrated that in the absence of further digoxin therapy, serum levels remained almost constant with mean changes of less than $+0.1 \mathrm{ng}$. We observed elevations of +0.2 and $+0.3 \mathrm{ng} / \mathrm{ml}$ in only two patients who had peroperative decreases in serum digoxin.

Coltart et al. ${ }^{36}$ observed a mean increase of $+0.2 \mathrm{ng}$ above induction values when they compared samples taken after induction and 16 hours after bypass when their hypothermic patients were rewarmed. The mean postoperative elevation in the series of Morrison et al. ${ }^{87}$ was +0.1 ng.

The information from these three series suggests that cardiopulmonary bypass is not associated with profound changes in serum digoxin concentrations. Transient minor decreases during and immediately after bypass may be due to dilution of plasma with the pump prime and intravenous transfusions. Postoperatively plasma levels may show very minor increases in a few patients which may be related to redistribution from tissue stores. The absence of a decrease in digoxin values during the first post-operative day is probably due to diminished glomerular filtration in the early postoperative period.

\section{Postoperative Dicoxin Intoxication}

While the patients in this series have demonstrated stable digoxin levels after cardiopulmonary bypass, the following cases illustrate the hazards of excessive post-operative therapy.

A previously digitalized patient developed pulmonary oedema and a sinus tachycardia during the first post-operative evening. Digoxin had been discontinued 48 hours before surgery. A house surgeon ordered digoxin $0.25 \mathrm{mg}$ stat. and $0.25 \mathrm{mg} \mathrm{q} .4 \mathrm{~h}$., to be withheld only if the ventricular rate fell below 80 beats/ minute. It should be emphasized that one cannot anticipate that sinus tachycardia will slow as a response to adequate digitalis therapy. Despite some clinical debate the patient received $1.5 \mathrm{mg}$ before digoxin was discontinued. 


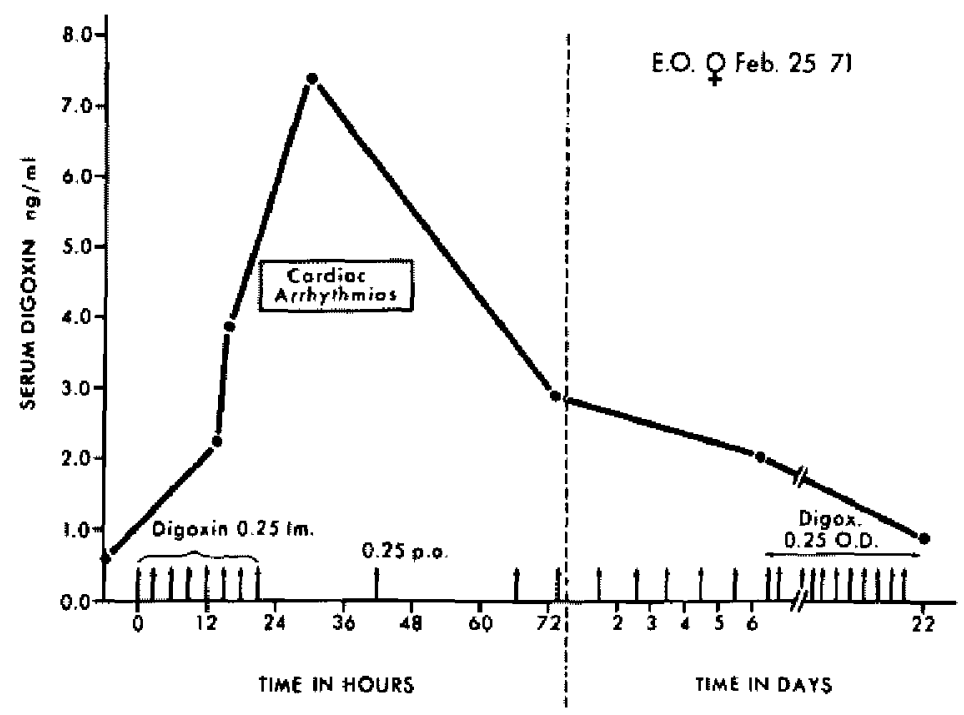

Figune 6, Postoperative digoxin intoxication.

Serum had been drawn two hours before this aggressive therapy was instituted. When this specimen could be analyzed later, serum digoxin was found to have been $0.5 \mathrm{ng} / \mathrm{ml}$. Ten hours after digoxin was discontinued the serum level was $7.4 \mathrm{ng} / \mathrm{ml}$ (Figure 6). Multiple premature ventricular contractions were noted in this period.

This patient's extremely elevated serum digoxin is the highest that has been observed in this hospital and exceeds those recorded during the assessment of two cases of accidental digoxin poisoning. Fortuitously, both the iatrogenically and accidentally poisoned patients had high normal serum potassium concentrations and maintained good renal function.

Two other cardiopulmonary bypass patients not in this series were not so fortunate. After postoperative emergency digoxin therapy of $1.5 \mathrm{mg}$ digoxin in the presence of inadequate renal function, both patients passed into acute renal failure with excessive digoxin concentrations of 4.8 and $2.9 \mathrm{ng} / \mathrm{ml}$. The nephrologosist was concerned that after dialysis these patients might exhibit intoxication when their serum potassium values were reduced. Both patients expired in the early postoperative period.

These cases emphasize the hazard of rapid digitalization in the early postoperative period. Postoperatively, digoxin should be employed in small doses with frequent clinical assessments of response to therapy. Radioimmunoassay can be used as a guide to management. Preoperative control is to be preferred.

\section{Serum Digoxin Changes after Cardioverion}

Since serum digoxin levels had been observed to remain stable following defibrillation during cardiac surgery, the series was extended to include five patients with atrial fibrillation or flutter who experienced successful elective cardioversion. 
Thiopentone, nitrous oxide and halothane or intravenous diazepam were employed for anaesthesia. Serum samples were obtained before cardioversion and five mirntes and three hours after cardioversion. In every case, serum digoxin values remained stable and any changes were within the range of variation of the test throughout the period of study.

This evidence supports the contention of Chamberlain et al..$^{88}$ that the digitalis toxicity sometimes noted after cardioversion may reflect excessive therapy prior to cardioversion which cannot be detected until the patient reverts to sinus rbythm.

\section{Cardlac Dyskhythmias}

Vanik and Davis ${ }^{39}$ have observed a high incidence of dysrhythmias in digitalized patients during anaesthesia.

None of the patients in this series required dysrhythmosuppressive therapy during surgery. Transient dysrhythmias were noted at the time of intubation and after cardiopulmonary bypass.

Serum digoxin radioimmunoassay was requested on seven other patients when dysrhythmias were noted. Two patients with rapid atrial fibrillation were inadequately digitalized. One of these patients was receiving $0.25 \mathrm{mg}$ b.i.d. orally, but had a malabsorption syndrome. Five other patients with junctional rhythms or ventricular premature beats did not have digoxin excess.

As an example, a patient with periodic second degree heart block (Wenckbach phenomenon) was suspected of digoxin intoxication. A blood sample was taken and digoxin was withheld. The heart block did not resolve. The serum digoxin was only $0.6 \mathrm{ng} / \mathrm{ml}$.

Additional and potentially remediable causes for dysrhythmias, which the clinician must consider in the digitalized patient, include electrolyte imbalance, hypoxaemia, acidosis, catecholamine release and other factors affecting the previously handicapped myocardium.

\section{SUMMARY}

Several points of interest have been demonstrated.

Serial testing has not shown any evidence of significant redistribution of digoxin from peripheral tissues during spinal anaesthesia, general anaesthesia or cardioversion. Serum levels remained almost constant during surgery and in the early post-operative period. Major blood loss and replacement during cardiopulmonary bypass has not caused a significant loss of digoxin.

Four clinical applications of the test are presented in Table II.

Preoperatively some patients are inadequately or excessively digitalized at the time of surgical stress. While digoxin intoxication is dangerous, inadequate treatment or protracted preoperative withdrawal of therapy may precipitate acute postoperative cardiac failure.

Radioimmumoassay provides the clinician with a technique of determining the preoperative serum digoxin and a rational approach to preoperative adjustments in therapy, so that the patient may come to surgery with an improved digoxin concentration. Preoperative control may diminish the need for aggressive use of digoxin in the early postoperative period. 
TABLE II

Anaesthetic Applications of Serum Digoxin Radiolmmunoassay

1. Preoperative assessment of maintenance therapy

2. Preoperative adjustment of therapy

3. Investigation of dysrhythmias and susperted digoxin intoxication

4. Improved prophylactic digoxin therapy

Serum digoxin radioimmunoassay plays an important confirmatory role in the investigation of operative and postoperative cardiac dysrhythmias and digoxin intoxication.

In the future, this assay will encourage a more rational resolution of the continuing surgical ${ }^{40,41}$ and anaesthetic ${ }^{42,43}$ debate on the role of prophylactic digitalization prior to major surgery. Excessive dosage schedules employed in the past may have precipitated digitalis intoxication at the time of surgery. This factor can be excluded by radioimmunoassay.

In conclusion, serum digoxin radioimmunoassay is an accurate test which can be an important aide in the anaesthetic management of patients requiring digoxin therapy.

\section{RÉSUMÉ}

Le radioimmunoassay de la digoxine sérique procure aux cliniciens une évaluation précise des taux de digoxine sérique. Ces données peuvent être précieuses pour aider à prendre des décisions chez les malades qui doivent être soumis à la chirurgie et qui ont besoin d'une thérapie à la digoxine. D'autres chercheurs ont reconnus qu'une intoxication à la digoxine est très souvent notée lorsqu'on trouve des concentrations de digoxine serique dépassant 2.0 nanogrammes par millilitre de sérum.

Au cours de lanesthésie, des évaluations du sérum noont pas donné de signe d'une redistribution significative soit au cours d'une anesthésie rachidienne, soit au cours d'une anesthésie générale ou d'une cardioversion. La perte et le remplacement d'une importante quantité de sang au cours de la circulation extracorporelle n"a pas entrainé une perte notable de digoxine.

En pratique de l'anesthésie, le radioimmunoassay de la digoxine serique peut avoir plusieurs applications; entre autres:

(1) L'évaluation pré-opératoire de la thérapie de maintien.

(2) La mise à point pré-opératoire de la thérapie dans le but d'éviter l'intoxication à la digoxine ou la sousdigitalisation.

(3) La recherche de dysrythmie d'intoxication digoxique appréhendée.

(4) L'amélioration de la thérapie digoxique prophylactique.

\section{ACKNOWLEDGEMENTS}

I would like to express my gratitude to Dr L.C. Jenkins, Professor and Head, Department of Anaesthesia, University of British Columbia and Dr Robert $T$. Morrison, Director of the Department of Nuclear Medicine, Vancouver General Hospital for their support of this investigation. Dr G.E. Wilkins pioneered the application of serum digoxin radioimmunoassay at the Vancouver General Hos- 
pital and made this project possible. I am deeply indebted to Miss Marilyn Pringle and Miss Elizabeth Louise Archibald of the Department of Nuclear Medicine and to Mrs Myrtle Robertson of the Department of Anaesthesia for many hours of voluntary assistance.

\section{APPENDIX

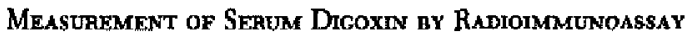

DF. G. E. Wrukans"

Serum digoxin levels may be determined by radioimmunoassay. The measurement involves the competitive binding of tritum labelled digoxin and unlabelled digoxin, either in known amounts or in a serum sample, with an antibody which is specific for digoxin. The amount of tritiated digoxin bound to the antibody is inversely related to the concentration of unlabelled digoxin which is present.

The bound and free digoxin are separated using dextran-coated charcoal. The free digoxin traverses pores in the dextran and is adsorbed by the charcoal, whereas the digoxin bound to the antibody is too large to traverse the dextran to be adsorbed by the charcoal. After centrifugation and separation, the bound radioactivity is determined using a liquid scintillation counter. A standard curve is prepared which relates the percentage of labelled digoxin bound to the antibody with known amounts of unlabelled digoxin. Serum samples are processed by determining the percentage binding of labelled digoxin in the presence of a standard volume of serum. The results are then read from a standard curve.

\section{Matergals and Methods}

The materials were provided by a commercial supplier.

1. Antibody specific for digoxin

2. Digoxin labelled with tritium Activity 0.3 microcuries $/ \mathrm{ml}$

3. Digoxin standard not labelled with radionuclide Concentration 40 nanograms $/ \mathrm{ml}$.

4. Scintillation medium Unogel ${ }^{\text {TM }}$

Sixteen $12 \mathrm{~mm} \times 75 \mathrm{~mm}$ polystyrene tubes were prepared containing 200 microliters serum from a serum pool. This pool was collected from laboratory persomnel not taking digoxin. Then 800 microliters of phosphate buffered saline was added $(0.01 \mathrm{M}$ phosphate, $0.15 \mathrm{M}$ $\mathrm{NaCl}_{\text {, }}$ plf 7.4). Digoxin standard was added to duplicate tubes in concentrations from 0.4 $\mathrm{ng} / \mathrm{ml}$ to $10.0 \mathrm{ng} / \mathrm{ml}$. Then 10 microliters of antiserum and 10 microliters of tritiated digoxin (containing 0.003 microcuries) were added to each tube. All tubes were incubated at room temperature for 30 minutes. Dextran coated charcoal was added to each tube. After ten minutes the tubes were centrifuged at $23^{\circ} \mathrm{C}$ and $1000 \mathrm{G}$ for ten minutes. Scintillation vials were prepared containing $10 \mathrm{cc}$ of Unogel. The supernatant from the test tubes was added to the scintillation medium.

Into two additional seintillation vials was added to microliters of tritiated digoxin, 200 microliters of serum and 800 microliters phosphate buffered saline. These vials were counted to determine the total sample count and the results formed the denominator of the equation for determining percent binding.

In measuring serum samples containing unknown amounts of digoxin, the steps were identical to above except that 200 microliters of seram was added to the reaction instead of a known amount of digoxin. All samples were done in duplicate. The serum was stored at $4^{\circ} \mathrm{C}$ and assayed within four days. In an emergency the results could be available in four hours.

Serum acts as a quencher and, therefore, all scintillation vials must be corrected. This was done by external cesium standarc. A quench correction curve relating efficiency to external standard was prepared with each new pool of serum used in the standard curve. A computer was programmed to convert counts per minute (cpm) to disintegrations per minute (dpm) using the external standard as a correction factor.

The percentage uptake of tritiated digoxin by the antibody was then calculated by: $d_{p m}$ in supenatant / dpm in total sample count $\times 100=$ Per cent uptake.

A standard curve was then prepared on semilogarithmic paper by plotting the percent of tri-

"Department of Nuclear Medicine, The Vancouver General Hospital. 


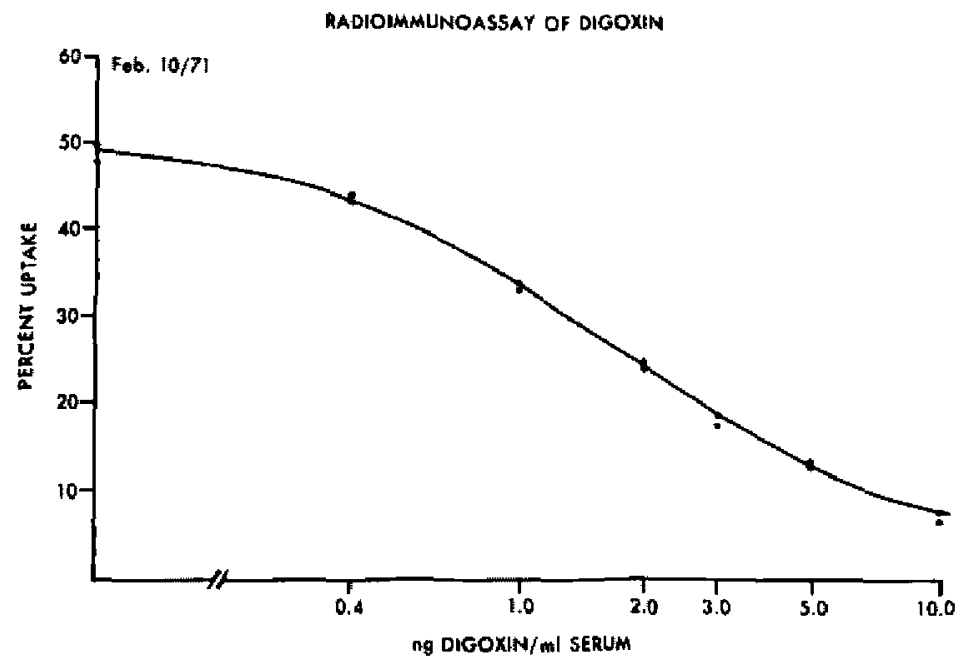

Figune 7. Standard curve for radioimmunoassay of digoxin.

tiater digoxin bound to antibody versus digoxin added in nanograms $/ \mathrm{ml}$. The digoxin concentration was the logarithmic function (Figure 7). The value for the unknown serum sample was read from the standard curve.

\section{COMMENTS}

The standard curve was reproducible with very little variation between duplicate values. Standard deviation for replicate samples was less than four per cent. Eighteen standard curves were virtually identical. Values of digoxin as low as $0.2 \mathrm{ng} / \mathrm{ml}$ gave an easily measured result.

The liquid scintillation mediun was very satisfactory as assessed by these criteria:

(a) Scintillation vials were counted continuously for 63 hours with each vial counted 13 times. The maximal deviation was 2.3 per cent with most values being within 1 per cent on repeated determinations. The vials were then counted eleven days later and the per cent variation was less than 2 per cent from original counts. This demonstrated that the scintillation medium was constant.

(b) Serum was the only quencher. The addition of unlabelled digoxin to scintillation vials containing tritiated digoxin did not alter the tritium spectrum.

(c) The efficiency for tritium in the scintillation medium varied only from 30 to 34 per cent.

The specificity of the antibody has been studied by adding inereasing amounts of antibody to a series of test tubes containing constant volumes of tritiated digoxin, (Figure 8). As expected, the amount of radioactivity in the supernatant increased with increasing amounts of antibody. The amount of antibody used in the assay is 10 microliters and this provided 50 per cent binding.

Serum digoxin levels were determined on nine normal laboratory personnel not taking digoxin and a zero value was found in all. One sample was determined on eight occasions for in-run replicability. The mean and standard deviation was $2.25 \pm 0.05 \mathrm{ng} / \mathrm{ml}$. One sample was done in duplicate on four occasions over an eleven day period. The mean was $1.49 \pm 0,008 \mathrm{ng} / \mathrm{ml}$. One other sample was done in duplicate after a 22 day interval with two different kits. The results were $2.05 \pm 0.02 \mathrm{ng} / \mathrm{ml}$

In summary, serum digoxin radioimmunoassay provides and sensitive and reproducible analysis of serum digoxin concentrations.

\section{REFERENCES}

1. Belcep, G. A., SMrth, T. W., Abelmann, W. H. HAaer, E. \& Hoon, W. B. Digitalis intoxication: clinical correlations with senum levels. New England J. Med., 284: 989 (1971).

2. DoHERTy, J. E. The clinical pharmacology of digitalis glycosides: a review. Am. J. M. Sc. 255: 382 (1968). 


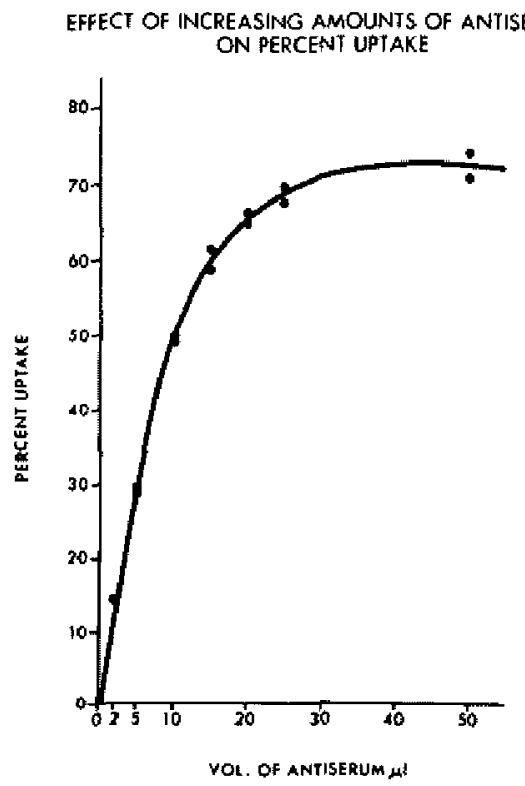

Figure 8

3. Doherty, J. E., Penxuns, W. H., \& Mrrchele, G. K. Tritiated digoxin studies in human subjects. Arch. Int. Med., 108: 53 I (1961).

4. Heizer, W. D., SMTTH, T. W., \& GoldFINGER, S. E. Absorption of digoxin in patients with malabsorption syndromes. N. England J. Med., 285: 259 (1971)

5. Doherty, J. E., Perrens, W. H., Flanigan, W. J. The distribution and concentration of tritiated digoxin in human tissues. Ann. Int. Med., 66: 116 (1967).

6. Ibid.

7. Ibid.

8. Lukas, D. S. \& Demartino, A. G. Binding of digoxin and some related cardenolides to human plasma proteins. J. Clin Invest., 48: 1041 (1969).

9. DOHERTY, J. E. Am. J. M. Sc., 255: 382 (1968).

10. Doherty, J. E., \& Perkuss, W. H. Studies following intramuscular tritiated digoxin in human subjects. Am. J. Cardiol., 15: 170 (1965).

11. Jelliffe, R. W. An improved method of digoxin therapy. Ann. Int. Med., 69: 703 (1968).

12. Ibid.

13. Doherty, J. E., Flanigan, W. J., Murphy, M. L., Bullock, R. T., Dalfymple, G. L., Beard, D. W. \& Petuss, W. H. Tritiated digoxin; XIV. Enterohepatic circulation, absorption and excretion studies in human volunteers. Circulation, 42; 867 (1970).

14. JeLLLFFe, R. W. Ann. Int. Med., 69: 703 (1968).

15. Ackemman, G. L,, Doherty, J. E., \& Flanican, W. J. Peritoneal dialysis and hemodialysis of tritiated digoxin. Ann, Int. Med., 67: 718 (1969).

16. DohretY, J. E. et al. Ann. Int. Med., 66: 116 (1967).

17. Roberce, G., Marcus, F. I., Kapadia, G. G., \& Lown, B. Digitalization of the myocardium in the intact animal by direct coronary artery drug administration. Am. J. Cardiol, 26: 365 (1970).

18. White, R. J., Chamberlain, D. A., Howard, M. R, \& SMith, T, W. Plasma concentrations of digoxin after oral administration in the fasting and postprandial state. Brit. M. J., I: 380 ( 1971 ).

19. Bhown, C., Doherty, J. E., \& Munphy, M. Lr Tissue concentrations of tritiated digoxin in dogs after oral administration. Clinical Research, 15:24 ( I967). 
20. Dohenty, J. E. \& Perkins, W. H. Tissue concentration and turnover of tritiated digoxin in dogs. Am. J. Cardiol., 17: 47 (1966).

21. Lowenstein, J. M. \& Connil, E. M. An improved method for measuring plasma and tissue concentrations of digitalis glycosides. J. Lab. \& Clin, Med., 67: 1048 (1966).

22. BRooker, G. \& Jelciffe, H. W. Determination of serum digoxin by enzymatic isotopic displacement of $\mathrm{H}_{3}$ digoxin from $\mathrm{Na}-\mathrm{K}$ ATPase. Fed Proc, 28: 608 (1969).

23. SMith, T. W., Butr.er, V. P., \& HABEa, E. Determination of therapeutic and toxic serum digoxin concentrations by radioimmunoassay. New England J. Med., 281: 1212 (1969).

24. Evered, D. C., Chapman, C., \& Hayter, C. J. Measurement of plasma digoxin concentration by radioimmunoassay. Brit. M. J, 3: 427 (1970).

25. SMrrT, T. W. et al. N. England Med. J., 281:1212 (1969).

26. Chamberlain, D. A, White, R. J., Howaro, M. R., \& SMith, T. W. Plasma digoxin concentrations in patients with atrial fibrillation. Brit. M. J., 3:429 (1970).

27. Beller, G. A. et al. N, England J. Med., 284: 989 (1971).

28. SMITH, T. W. \& HABER, E. Digoxin intoxication: the relationship of clinical presentation to serum digoxin concentration. J. Clin. Invest., 49: 2377 (1970).

29. Hoeschen, R. J. \& PhoveidA, V. Sertum digoxin by radioimmunoassay. Canad. M. A. J., I05: 170 (1971).

30. Beuler, G. A. et al. New England J. Med., 284: 989 (1971).

31. Chamberlain, D. A. et al. Brit. M. J., 3; 429 (1970).

32. VANIK, P. E. \& DAyis, H. S. Cardiac arrhythmias during halothane anesthesia, Anesth. \& Analg., 47: 299 (1968).

33. Beall, A. C., Johnson, P. C., Diuscoll, T., Alexander, J. K., Dennis, E. W., McNamara, D. G., ConceY, D. A., \& Debakex, M. E. Effect of total cardiopulmonary bypass on myocardial and blood digoxin concentration in man. Am. J. Cardiol, 11: 194 (1962).

34. Monfison, J., Kullup, $\mathrm{T}_{\text {, }}$ Staşon, W. B. Serum digoxin levels in patients undergoing cardiopulmonary bypass. (Abstract) Circulation, 42 (Suppl. 1FI): 110 (1970).

35. Coltaft, D. J., Chamberlain, D. A., Howafd, M. R., Ketrínwell, M. G., Mercen, J. L., \& SMITH, T. W. Effect of cardiopulmonary bypass on plasma digoxin concentrations.

36. Ibid. Brit. Heart. J., 33: 334 (1971).

37. Monuson et al. Circulation, 42 (Suppl. III) : 110 (1970).

38. Chamaerlain, D. A et al. Brit. M. J., 3: 429 (1970).

39. VANiK, P. E. \& Davis, H. S. Anesth. \& Analg., 47: 200 (1968).

40. Jul,en, G. L., STemmer, E. A.. \& Connoley, J. E. Complications of prophylactic digitalization in thoracic surgical patients. J. Thoracic \& Cardiovase. Stirg, 58: 352 (1969).

41. SElzEr, A. \& Cors, K. E. Some thoughts concerning the prophylactic use of digitalis (Editorial) Am. J. Cardiol, 26: 214 (1970).

42. DeUtsch, S. \& DaLEN, J. E. Indications for prophylactic digitalization. Anesthesiology, 30 : $648(1969)$.

43. Strong, M. J. \& Kents, A. S. Digitalis and heart disease (Cortespondence) Anesthesiology, 31: $583(1969)$. 